\title{
The Differences Between the Kerinci Greeting Words in Dialect of Jujun with Dialect of Lolo
}

\author{
Dedi Saputra ${ }^{1, *}$ Ermanto $^{1}$ \\ ${ }^{1}$ Universitas Negeri Padang, Padang, Indonesia \\ *Corresponding author. Email: dedisaputradhey@gmail.com
}

\begin{abstract}
This study aims to describe and explain the differences in the greeting words of the Kerinci language in the Jujun dialect and the Lolo dialect. This research utilizes a qualitative descriptive method and does not utilize statistical formulas when processing data. Researchers found 42 greeting words for the Kerinci language in the Jujun dialect consisting of 32 general greeting words, 6 costumary or traditional greeting words, and 4 religious greeting words. The researcher also found that there were 52 greeting words for the Kerinci religious greeting words.language in the Lolo dialect consisting of 37 general greeting words, 5 costumary or traditional greeting words, and 10 religious greeting words. From this research we will know there are many differences between the greeting words in dialect of Lujun with dialect of Lolo.
\end{abstract}

\section{Keywords: Dialects, Greetings, Local languages, Speech}

\section{INTRODUCTION}

Regional languages over time experience erosion due to the influence of foreign languages and national laguages that are upheld by Indonesian state. This is because in the world of education, English is almost the language of the interface as well as other foreign languages which have a strong position such as mandarin, Arabic, and Spanish. This also has an impack on greeting words that exist in the area being forgotten due to the mushrooming of foreign greetings. The greeting words of father and mothe in Jujun village are Abak or Apiak and Induok or Mak. And in Lolo village are Abak and Mak are replaced with greeting words such as the use of the words father and mother with daddy and mommy, which is translated from English. In another hands to call father and mother also replaced with Arabic with Abi and Umi also Papa and Mama in Indonesia.

There are two factors causing the extinction of regional languages in Indonesia, namely internal factors and external factors. Regarding internal factors, namely (1) economic factors, (2) educational curriculum disorientation, (3) weakening of socialization in the family, (4) lack of awareness of younger generation, and (5) cultural domination by the majority community. Then the external factors include: (1) modernization and globalization, (2) inter-ethnic marriages, (3) the existence of foreign languges in Indonesia, and (4) cultural domination [1]. On the other hand Wolfram [2] said when dialect or local language lost there are no identity and unique part of human knowledge and culture again of some island who lost it.

Greeting words are used when talking to the interloculator in a situation or context. Regional greeting words refer to the use of regional languages in the form of greeting. Regional greeting words will always exist when preserved by the speakers. Regional greeting words will disappear if we are not preserved and passed down from one generation to the next. Parents are obliged to teach their children to use regional greeting words so that the sustainability of regional greeting words is maintained from time to time.

Skirgard et al. [3] said a language will be confused like greeting words when the language or greeting words is rarely heard by someone, therefore to avoid this, of course a breakthrough is needed by getting used to hearing language or greeting words in order to avoid this confusion becoming a habit. In another ways McCullough et al. [4] there are two kind perception of regional dialect variation namely: (1) Adult perception, and (2) Children's perception who across the lifefan: identification and discrimination. On the other hand Al-thubaity et al. [5] said most study in Arabic focused on MBA of local dialect.

This research is very important to preserve and introduce regional languages in the Kerinci district dialect of Jujun village and Lolo village and what is the difference between the greeting words between these two villages. Jujun village and Lolo village are two villages that are close to each other. Jujun village consists of 5 villages in it namely, Jujun village, Pasar Jujun village, Koto Baru village, Koto Agung village and Talang Lindung village. While Lolo village consists of 2 villages, namely Lolo Gedang and Lolo Kecil. The diversity of languages in Kerinci Regancy is very unique and interesting and one of examples can seen from this study, namely the differences between Kerinci greeting words in Jujun and Lolo dialect. 
Researcher hopes this research will make the world aware of the uniqueness and diversity that exists in this Kerinci district. On the other hand, this research also contributes to science and education, especially in the field of language.

Kridalaksana in Misnawati [6] there are 9 types of greeting words in Indonesia, namely:

1. Pronouns. Fpr examples: I, You, We, They, He, She, and It.

2. Self-name. For examples: Mira, Nana, Rehan, Adi, Tina, so on.

3. The term kinship. For exampes: Brother, Sister, Granfather, Grandmother, Mother, Father, Son, Daughter, Aunt, Uncle, so on.

4. Title and rank. For examples: Doctors, Generals, Lecturers, Teachers, so on.

5. The form pe $+\mathrm{V}$ (verb). For examples: Actors, Bankers, Enterpreneurs, so on.

6. Facts about deixis or pointers. For examples: that, this, these, and those.

7. Nouns or objects. For examples: Mr, Mrs, Lady, Master, so on.

8. Form my + noun . For examples: my bicycle, my pencil, my book, my dear, so on.

9. Zero or zero. For examples: when the person said "go to school?", the word "I" is not mentioned, it should be "I go to school". That means without my words, the sentences can be interpreted.

There has been a lot research on dialect and greeting words both internationally and in Indonesia. Some examples of international research on dialects and greeting words are as follows. Potter \& Saffran [7] who research about exposure to multiple accents supports infants understanding of novel accents, in this research they found infents failure to recognize familiar words spoken, manipulated variability by including speaker, only older infants exploited the additional variability and the process of discovering which features of speech can be ignored is not trivial. Myersburg [8] with the title of research the role of dialect words in children's social decision. In this research found the fact that participant individual responses to preference question did not predict individual responses to the selective trust question. Wagner et al. [9] who research about children's perception of dialect variation. In this research found that children's have limited ability to use dialect in an explicit categorization task replicated from the literature.

On the other hand, Setiawan [10] did research about social dialect variations in Sasak monolingual society. In his research found social dialect in Sasak monolingual societies on social existence during the speech in various contexts, such as talking to people of lower social class, less educated, and less influential in the conversation. As Shariati \& Tayebi [11] did research about perspective evaluation of levenshtein dialect distance measurements using Norwegian dialect data. In this research found fifhteen Norwegian dialects were included in study, perceptual distances calculated in Lavenshtein distances.

Shariati \& Tayebi [11] researched about a comparative study of proverbs charasteristics of Mesopotamian language and a local dialect of Persian. In this result he found 5 types of provers, namely: (1) the use of proverb of instruction, (2) proverbs are international, (3) proverbs are spoken, (4) proverbs are not coined by academics, and (5) proverbs are multifunction. Karacan [12] in his research with title Kurmanji and Zazaki dialects: comperative study on their phonetics found the similarities between Zazaki and kumanji show that there is more dialectical closeness than that between two languages, and that we are left with the similarities of them.

Barbu et al [13] researched about the maintenance of regional dialects: a matter of gender? Boys, but not girls, use local varieties in relation to their friends nativeness and local identity and found two kind of varian in local dialect language, its are: (1) Children productions of the regional variant of $(\mathrm{Y})$, and (2) Childrens production of the non standart variant $f$ general French (VL). Paquette-smith el al. [14] in their researched the effect of accent exposure on children's sosiolinguistic evaluation of Peers found there are 3 types of effect of accent in dialect of children's, namely: (1) Low effect. (2) Medium effect, and (3) High effect.

Al-Qaderi [15] did research about convensational implicature in Arabic: a pragmatic analysis of applying flouting the maxims to the Yemeni dialect found maxim quantity is the most usefull maxim than another maxim. Gong et al. [16] researched about cultural diversity in China: dialect, job embeddedness, and furnover found in China there are variations of cultural diversity and make that be balance each other among dialect, job embeddedness, and furnover.

Above have presented several international articles that discuss about dialects, but none have specifically discussed addressing words in their respective regions. However, the researcher also prepared several studies in Indonesia that specifically discussed greeting words in certain regional dialects.

The first topic greeting words in Banten dialect made by Indrawaswari [17] In this research she found 3 types of greeting words in Banten dialect, namely: (1) Greeting words in nucleous family, (2) Greeting words in extended family, and (3) Greeting words in neighborship. Then Setyarini [18] did research about analysis of the use of football tabloid news title greeting words, in this result She found 4 types of greeting words, its are (1) Greeting words related to physical form, (2) Greeting words related to nature, (3) Greeting Words related to real name, and (4) Greeting words related to the name of the animal.

Perwira [19] did research about variations of the language of greeting words buying and selling Klitikan market in Semanggi Surakarta in December 2012, in this result he found (1) the greeting language used in speeches about traders in the Klitikan market in Surakarta is brother, sis, sir, ma'am, uncle, mister, and names, (2) The variety of language greetings for traders in Klitikan Semanggi market in Surakarta include a variety of greeting languages using pronouns or kinship, and (3) The factors behind the use of greeting language to traders are social class, gender, ethnicity and age. Rusbiyantoro [20] did research about use of greeting words in the Malay language Kutai, in this 
research found : (1) use of greeting words based on kinship, (2) The pronoun person, (3) Form of self-name, (4) Form of peerage, (5) Zero form, (6) Nickname form, and (7) greeting words that have a plural meaning. Misnawati [6] with the title of research is MinangKabau Greeting words and found 3 types of greeting words, namely: (1) General greeting words, (2) Costumary greeting words, and (3) Religious greeting words. And the last researched by Aditama [21] about the use of Kerinci greeting in Jujun dialect and he found 3 kinds of greeting words as same as like Misnawati with: (1) General greeting words, (2) Costumary greeting words, and (3) Religious greeting words.

From many studies on greeting words. The researcher did not find a single study that examined the differences between Kerinci greeting words in Jujun dialect with Lolo dialect. Eventhough in 2020, Adiatama research the use of the greeting words in Jujun village. From these results there are still some developments that the researchers explain in this study and will compare with Lolo dialect. Then finally the research will show the differences between these two village dialects.

\section{METHOD}

This study uses a qualitative descriptive method without using statistical formulas and calculations at all. Descriptive research method is a research method that describes the social phenomena or symptoms under study by independenly describing the value of the variables [22]. On the other side Sugiyono [23] explain that qualitative research method is researche method based on postprositivism used to examine natural objects and the results of research emphasize meaning rather than generalization.

The data in this study are in form og greeting words from Kerinci community in Jujun village and Lolo village. The data source came from 4 informants. 2 are original residents of Jujun village and 2 others are native in Lolo village. The first informant was Mrs. Nurwaida, S. Pdi (58) and the second informant was Mr. Nasri (61) who was a resident of the original Jujun who stay in Koto Agung village to be precise. For Lolo village is the informants from Lolo Kecil village. The first informant was Mr. Andika Saputra (25) and the second informant was Mrs. Ika Harleni (38).

The data collection techniques change proficient techniques using basic fishing techniques and advanced face-to-face techniques. Mahsun [24] explain that the proficient method of collecting data by talking to one another between researchers and informants. He adds that inducement techniques are techniques in interviews by providing inducements in the form of questions and attitudes to get the response the researcher wants.

Data analysis technique using intalingual matching method. Mahsun [24] explains intralingual matching method is a method analysis using linking elements that are lingual both in one language and in several different languages.
Data are presented in informal method. Furthermore, he explains that the researcher only presents the data in the form of regular greetings without any particular symbol. Informal research method is the formulation of research in ordinary words including using technical terminology.

\section{RESULT AND DISCUSSION}

The results of this study are divided into 3 parts, namely (1) The greeting words for the Jujun dialect, (2) The greeting words for Lolo dialect, and (3) The differences between Kerinci greeting words in Jujun dialect with Lolo dialect. Then the greeting words in this study are divided into 3 greeting words, its are 1) General greeting words, (2) Costumary greeting words, and (3) Religious greeting words.

\subsection{Greeting Words in Jujun Dialect}

3.1.1 General Greeting Words In Jujun Dialect

3.1.1.1 Greeting words of Apiak or Abak and Induok or Mak.

Greeting words Apiak or Abak to call father in Jujun dialect and Induok or Mak to call mother in Jujun dialect. Example in daily corversation:

Table 1 : Greeting words of Apiak or Abak and Induok or Mak

\begin{tabular}{|l|l|}
\hline Jujun Language & English \\
\hline Apeoa Apiak buh? & Who is your Father? \\
\hline Abak bu gi kanoa? & Where are your Father? \\
\hline $\begin{array}{l}\text { La udiah bu atoa kik } \\
\text { Induok buh? }\end{array}$ & $\begin{array}{l}\text { Did you say to your } \\
\text { Mother? }\end{array}$ \\
\hline Mak ku gi kahiet. & My Mother go to garden. \\
\hline
\end{tabular}

3.1.1.2 Greeting words of Mamak, Itek, Datuk, Nineak, Nunyang Jantien, Nunyang Tinuo, Mak Woa, and Yah Woa

Greeting word Mamak to call uncle in Jujun dialect. Greeting word Itek to call aunt. Greeting word Datuk to call Grandfather. Greeting word Nineak to call Grandmother. Nunyang Jantien to call father of Grandfather or Grandmother. Nunyang Tinuo to call mother of Grandfather or Grandmother. Mak Woa to call the oldest woman relatives of mother or father. Yah Woa to call the oldest man relatives of mother or father.example in daily conversation: 
Table 2 : Greeting words of Mamak, Itek, Datuk, Nineak, Nunyang Jantien, Nunyang Tinuo, Mak Woa, Yah Woa, Mak Ngah and Yah Ngah

\begin{tabular}{|c|c|}
\hline Jujun Language & English \\
\hline $\begin{array}{l}\text { Mamak lah udiah akaan } \\
\text { pagui? }\end{array}$ & $\begin{array}{l}\text { Do you have breakfast } \\
\text { Uncle? }\end{array}$ \\
\hline Itek soa ndak apel. & Aunt wants an apple. \\
\hline Datuk nak gi siyiang. & $\begin{array}{l}\text { Grandfather is going to } \\
\text { praying. }\end{array}$ \\
\hline Nineak lah & Grandmother was sleepimg. \\
\hline $\begin{array}{l}\text { Nunyang Jantien soa } \\
\text { ndak ayaek. }\end{array}$ & $\begin{array}{l}\text { Father of Grandfather or } \\
\text { Grandmother needs water. }\end{array}$ \\
\hline $\begin{array}{l}\text { Nunyang Tinuo nak gi } \\
\text { kabalie }\end{array}$ & $\begin{array}{l}\text { Mother of Grandfather or } \\
\text { Grandmother will go to } \\
\text { market. }\end{array}$ \\
\hline Mak & $\begin{array}{l}\text { My Oldest woman relatives } \\
\text { of mother or father is sick. }\end{array}$ \\
\hline Yah & $\begin{array}{l}\text { The Oldest relatives of } \\
\text { mother or father go to } \\
\text { jungle. }\end{array}$ \\
\hline Mak Ngah & $\begin{array}{l}\text { The middle relatives of } \\
\text { mother or father go to } \\
\text { Sungai Penuh. }\end{array}$ \\
\hline $\begin{array}{l}\text { Yah Ngah nak gi } \\
\text { laaut. }\end{array}$ & $\begin{array}{l}\text { The midlle relatives of } \\
\text { mother or father go to sea. }\end{array}$ \\
\hline
\end{tabular}

\subsubsection{Greeting words of Awak, Kayoa, and Cik}

The greeting word for people who are older than themselves call Awak. Kayoa is the greeting word in jujun dialect to call parents or elder the themselves and show the respect. The greeting word of $C i k$ to call a woman who has a daughter. Example in daily conversation:

Table 3: Greeting words of Awak, Kayoa, and Cik.

\begin{tabular}{|l|l|}
\hline Jujun Language & English \\
\hline Awak apeoa? & Who are you? \\
\hline $\begin{array}{l}\text { Kayoa ilaok lah gi nonton } \\
\text { ha maen voli. }\end{array}$ & $\begin{array}{l}\text { You are better to watching } \\
\text { vollyball, }\end{array}$ \\
\hline $\begin{array}{l}\text { Ilaok loa gadih'i anak wak } \\
\text { Cik }\end{array}$ & Your daughter is beautiful \\
\hline
\end{tabular}

3.1.1.4 Greeting words of Abang, Kakak, Adik Jantien or Adiek Jantien, Adik Tinuo or Adiek Tinuo, Apok, Induk, Kulaut, and Kanaut.

In Jujun greeting word to call old brother is Abang,to call old sister is Kakak,to call young brother is Adik Jantien or Adiek Jantien, to call Young Sister is Adik Tinuo or Adiek Tinuo. Apok is greeting word in jujun dialect when a child call a brother of his or her mother or father. Induk is grreting word when a child call a sister of his or her mother or father. Kulaut is greeting word to call a boy or man who has a big love from his family. Kanaut is greeting word to call a girl or woman who has a big love from her family. Example in daily conversation:
Table 4: Greeting words of Abang, Kakak, Adik Jantien or Adiek Jantien, Adik Tinuo or Adiek Tinuo, Apok, Induk, Kulaut, and Kanaut

\begin{tabular}{|l|l|}
\hline Jujun Language & English \\
\hline Abang nak gi kanoa? & $\begin{array}{l}\text { Where are you (old } \\
\text { brother) going? }\end{array}$ \\
\hline Kakak idiag aliek umiah? & $\begin{array}{l}\text { Do you (old sister) want to } \\
\text { go home? }\end{array}$ \\
\hline $\begin{array}{l}\text { Mpaon nak gi kanoa } \\
\text { Adik/Adiek? }\end{array}$ & $\begin{array}{l}\text { Where are you (young } \\
\text { brother) going? }\end{array}$ \\
\hline $\begin{array}{l}\text { Kaau Adik/Adiek idiag } \\
\text { aliek? }\end{array}$ & $\begin{array}{l}\text { Do you want (young } \\
\text { sister) to go home? }\end{array}$ \\
\hline $\begin{array}{l}\text { Duo wak gi maen bal } \\
\text { Apok? }\end{array}$ & $\begin{array}{l}\text { Are you going to playing } \\
\text { football Pok? }\end{array}$ \\
\hline $\begin{array}{l}\text { Induk gi nyampak sahap } \\
\text { I'm going to throw the } \\
\text { rubish. }\end{array}$ \\
\hline Nonton tipi lah Kulaut & $\begin{array}{l}\text { You can watching TV } \\
\text { honey. }\end{array}$ \\
\hline $\begin{array}{l}\text { Mak lah kaau masak } \\
\text { Kanaut }\end{array}$ & $\begin{array}{l}\text { You do not need to cook } \\
\text { honey. }\end{array}$ \\
\hline
\end{tabular}

3.1.1.5 Greeting words of Akau, Ikoa, Kaau, Kamai, Kitoa, Mpaon, and Nyoa.

Akau in Jujun greeting word means I, Ikoa means They, Kaau means to call she, Kamai to call we, kitoa to call we, Mpaon to call he and Nyoa to call object her or him. Examples in daily conversation:

Table 5: Greeting words of Akau, Ikoa, Kaau, Kamai, Kitoa, Mpaon, and Nyoa

\begin{tabular}{|l|l|}
\hline Jujun language & English \\
\hline Akau lah litak. & I'm tired. \\
\hline Ikoa nak gi kanoa? & Where are you go guys? \\
\hline Kaau bidan you? & Are you midwife? \\
\hline Kamai nak gi sula & We will go to school \\
\hline Kitoa lah kalah & We have been lose \\
\hline Mpaon lah tiduo? & Are you sleeping? \\
\hline $\begin{array}{l}\text { Sinta tadih aduo nyo } \\
\text { knik, tapi Nyoa lah aliek. }\end{array}$ & $\begin{array}{l}\text { Sinta was here before. But } \\
\text { she was going back to her } \\
\text { home. }\end{array}$ \\
\hline
\end{tabular}

\subsubsection{Customary Greeting Words in Jujun Dialect}

There are many customary greeting words in Jujun dialect its are Depati, Hulubalang, Ninik Mamak, Pemangku Adat, Pungkoa, dan Taganui. This greeting words not used everyday cause just only on some situation like when there is traditional party or traditional ceremonies. Depati is the greeting word like to call province in one nation. Indonesia like Jakarta province, Sumatra Selatan province, so on. There are many Depati in Jujun its are Depati Kujuo, Depati Jayuo, Depati Jujun, etc. Hulubalang is a person who has a job to handle some of job in Jujun village about tradition. Ninik Mamak is a person who everyperson in Jujun Village respected and handle some of consider of problem and something happen in Jujun village. Pemangku Adat is a person who society believe to handle some of problem or something happen in Jujun village. Pungkoa is like a big family or extended family member. Taganui is some of old peoples who in 
relationship with us and have a job to handle or consider of choices. Example in daily conversation:

Table 6: Greeting words of Depati, Hulubalang, Ninik Mamak, Pemagku Adat, Punkoa, and Tagunui

\begin{tabular}{|l|l|}
\hline Jujun Language & English \\
\hline $\begin{array}{l}\text { Anggota Depati Jayuo } \\
\text { rapat. }\end{array}$ & $\begin{array}{l}\text { Members of Jayuo Depati } \\
\text { is meeting. }\end{array}$ \\
\hline Hulubalang gi nyiap data & $\begin{array}{l}\text { Hulubalang is preparing for } \\
\text { data. }\end{array}$ \\
\hline Ninik Mamak lah tibuo. & Ninik Mamak arrived. \\
\hline Pemangku Adat lah gin & Pemangku Adat gone. \\
\hline $\begin{array}{l}\text { Pungkoa } \text { siaplah } \\
\text { Taganui gi nyelesae } \\
\text { masalah. }\end{array}$ & $\begin{array}{l}\text { Pungkoa should be ready. } \\
\text { problem. }\end{array}$ \\
\hline
\end{tabular}

\subsubsection{Religious Greeting Words in Jujun Dialect}

There are many religious greeting words in Jujun dialect, its are Buya, Guriu, Haji, and Hajjah. Buya is a man who has an education in religious. Guriu is greeting word to call teacher of religious in Jujun dialect. Haji is a call to a man who ever go to Mekkah in Haji mount. Hajjah is a call to a woman who ever Mekkah in haji mount. Examples in daily conversation:

Table 7: Greeting words of Buya, Guriu, Haji, and Hajjah

\begin{tabular}{|l|l|}
\hline Jujun language & English \\
\hline $\begin{array}{l}\text { Buya agui ceramah di } \\
\text { masjuit }\end{array}$ & $\begin{array}{l}\text { Ustadz is speeching in } \\
\text { mosque }\end{array}$ \\
\hline Guriu, ajia akau ngajui. & $\begin{array}{l}\text { Teacher, teach me to recite } \\
\text { please. }\end{array}$ \\
\hline Haji Saleh gi sibuk & Haji saleh is busy \\
\hline Hajjah Gustina gi gawie & Hajjah Gustina is working. \\
\hline
\end{tabular}

\subsection{Greeting Words in Lolo Dialect}

3.2.1 General Greeting Words in Lolo Dialect

3.2.1.1 Greeting words of Abak, Mak, Datung, Mamak, Itek, Pak Itek, Mak Tuo, Mak Cik, Mak Ngah, Pak Tuo, Pak Cik, and Pak Ngah

Abak is greeting word in lolo dialect to call father. Mak is greeting word to call mom. Datung is greeting word to call aunt. Mamak is greeting word to call uncle. Itek is greeting word to call aunty. Pak Itek is a husband of Itek or uncle. Mak Tuo is a greeting word to call the oldest sister of mother or father. Mak Cik is a greeting word to call the youngest sister of mother or father. Mak Ngah is a greeting word to call the middle sister of mother of father. Pak Tuo is a greeting word to call the oldest brother of mother or father. Pak Cik is a greeting word to call the youngest brother of mother or father. Pak Ngah is the middle brother of mother or father. Examples in daily conversation.

Table 8: Greeting words of Abak, Mak, Datung, Mamak, Itek, Pak Itek, Mak Tuo, Mak Cik, Mak Ngah, Pak Tuo, Pak Cik, and Pak Ngah

\begin{tabular}{|l|l|}
\hline \multicolumn{1}{|c|}{ Lolo Dialect } & \multicolumn{1}{c|}{ Englishs } \\
\hline Abak nak gi kano? & Where are you go Dad? \\
\hline Mak laudeah masak? & $\begin{array}{l}\text { Did you already to cook } \\
\text { Mom? }\end{array}$ \\
\hline Datung akeu ndek pisaang & Aunt I want a banana. \\
\hline Mamak knit awak. & Uncle please come here. \\
\hline
\end{tabular}

\begin{tabular}{|l|l|}
\hline Itek blui krita akeu. & Aunty buy a bicycle to me. \\
\hline Pak Itek masok mah saket & $\begin{array}{l}\text { Uncle is entering to } \\
\text { hospital. }\end{array}$ \\
\hline Mak Tuo lah siap? & Are you ready Mak Tuo? \\
\hline $\begin{array}{l}\text { Mak Cik mngih akeu } \\
\text { tadin. }\end{array}$ & $\begin{array}{l}\text { Mak Cik angry to me } \\
\text { before. }\end{array}$ \\
\hline Mak Ngah la tidu. & Mak Ngah slept. \\
\hline Pak Tuo la Litak. & Pak Tuo is tired. \\
\hline $\begin{array}{l}\text { Pak Cik bne laang ntuk } \\
\text { akeu. }\end{array}$ & Pak Cik make a kite for me. \\
\hline $\begin{array}{l}\text { Pak Ngah la udeah } \\
\text { mandui? }\end{array}$ & $\begin{array}{l}\text { Do you ready taking a bath } \\
\text { Pak Ngah? }\end{array}$ \\
\hline
\end{tabular}

3.2.1.2 Greeting Words of Nakek, Ninek, Nungguh, Nanggut, Uda, Abang, Une, Kakak, Nunyang, Mak Itam, Mak Utih, Mak Cu, Pak Itam, Pak Utih, and Pak $\mathrm{Cu}$.

Nakek is a call from grandson to father of mother. Ninek is a call from grandson to mother of mother. Nungguh is a call from grandson to mom of father. Nanggut is a call from grandson to father of father. $U d a$ to call older brother. Abang to call older brother too. Une is a call to older sister. Kakak to call older sister. Nunyang to call a call from grandson to mother or father of grandmother or grandfather. Mak Itam is a call to middle sister of mother. Mak Utih is a greeting word to call a middle sister of father. Mak $C u$ is a call to the youngest sister of mother. Pak Itam is a call to middle brother of mom. Pak Utih is a call to middle brother of father. Pak $\mathrm{Cu}$ is a greeting word to call youngest brother of mother. Examples in daily conversation:

Table 9: Greeting words of Nakek, Ninek, Nungguh, Nanggut, Uda, Abang, Une, Kakak, Nunyang, Mak Itam, Mak Utih, Mak $\mathrm{Cu}$, Pak Itam, Pak Utih and Pak $\mathrm{Cu}$

\begin{tabular}{|c|c|}
\hline Lolo Language & English \\
\hline $\begin{array}{l}\text { Nakek lom nyo bangkit } \\
\text { agi tidu. }\end{array}$ & Grandfather is still sleeping \\
\hline Ninek agui badua & Grandmother is praying. \\
\hline Nungguh lah tajatuh. & $\begin{array}{l}\text { Grandmother felt on the } \\
\text { floor. }\end{array}$ \\
\hline Nanggut maco bukiu & Grandfather reads a book. \\
\hline$U d a$ baunda & $\begin{array}{l}\text { My brother is riding a } \\
\text { motorcycle. }\end{array}$ \\
\hline Abang agui kinciang. & My brother is pee. \\
\hline Une nak gi kano? & Where are you going sister? \\
\hline Kakak gui ka bale. & $\begin{array}{l}\text { My sister go to traditional } \\
\text { market. }\end{array}$ \\
\hline Nunyang lah matoi. & Nunyang is dead. \\
\hline Mak Itam hak ladeng. & Mak Itam on the garden. \\
\hline Mak Utih hak Ipao. & Mak Utih in the market. \\
\hline Mak $\mathrm{Cu}$ hak skula. & Mak $\mathrm{Cu}$ in the school, \\
\hline Pak Itam main raket. & Pak Itam plays badminton. \\
\hline Pak Utih main bola. & Pak Utih plays football. \\
\hline Pak $C u$ hak Amerika & Pak Cu stay in America. \\
\hline
\end{tabular}


3.2.1.3 Greeting Words of Akeu, Mpuan, Kaau, Nyo, Iko, Anang, Kamui, Kito, Kayo, and Awak

Greeting word of Akeu in English is I, Mpuan is you for male, Kaau is you for female , Nyo is her or him, Anang is they, Kamui is we, Kito is we. Awak is a call for a person who older then someone. Kayo is a call for person who older the someone and show respected. Iko is they in English. Examples in daily conversation:

Table 10: Greeting words of Akeu, Mpuan, Kaau, Nyo, Iko, Anang, Kamui, Kito, Kayo, and Awak

\begin{tabular}{|l|l|}
\hline Lolo language & English \\
\hline Akeu nak gi sakula & I want to go to school. \\
\hline Mpuan lah tibo? & Do you arrived? \\
\hline Kaau lah maseak? & Do you already to cook? \\
\hline Nyo lah nangih & She or he is crying. \\
\hline Anang lah Baleah. & They are fighting. \\
\hline Kamui nak gui barlek. & $\begin{array}{l}\text { We will go to wedding } \\
\text { party. }\end{array}$ \\
\hline Kito mnang. & We win the contest. \\
\hline Awak kalah. & You Lose. \\
\hline Kayo lah balik? & $\begin{array}{l}\text { Are you going back to your } \\
\text { home? }\end{array}$ \\
\hline Iko lah balik? & Are they going back? \\
\hline
\end{tabular}

\subsubsection{Customary Greeting Words in Lolo Dialect}

There are many customary greeting words in Lolo dialect. Its are Depati, Datuk, Ninik Mamak, Sultan, and Puti or Putoi. As same as like Jujun village in Lolo Vilage Depati is like a province in one nation. Datuk is a old man who Lolo village society believe to handle and command all traditional activity. Ninik Mamak is a man who help and under the Datuk. Sultan is young man who has a right to command society in Lolo Village. Puti or Putoi is a woman who has right to command society in Lolo village. Examples in daily conversation:

Table 11: Greeting words of Depati, Datuk, Ninik Mamak, Sultan, and Puti or Putoi

\begin{tabular}{|l|l|}
\hline Lolo Language & English \\
\hline $\begin{array}{l}\text { Uhang Depati gui ke } \\
\text { pusko. }\end{array}$ & $\begin{array}{l}\text { Depati peoples are going to } \\
\text { traditional home. }\end{array}$ \\
\hline Datuk gui nganta breh. & Datuk is going to send rice. \\
\hline Ninik Mamak rapat. & Bibik Mamak is meeting. \\
\hline Sultan ideo umiah. & Sultan is not at home. \\
\hline $\begin{array}{l}\text { Puti atau Putoi gui hak } \\
\text { acara. }\end{array}$ & Puti or Putoi goes to event. \\
\hline
\end{tabular}

\subsubsection{Religious Greeting Words in Lolo Dialect}

There are many religious greeting words in Lolo dialect. Its are Nanggut, Nungguh, Une, Abang, Bapak, Ibuk, Ustad, Ustadzah, Haji, and Hajjah. Greeting words of Nanggut, Nungguh, Une, Abang, Bapak and Ibuk is greeting words to call teacher who teach in religion. Ustad is a man who have an education in religion. Ustadzah is a woman who have an education in religion. Haji is a man who ever go to Mekkah in Haji Month. Hajjah is a woman who ever go to Mekkah when Haji month. Examples in daily conversation:
Table 12: Greeting words of Nanggut, Nungguh, Une, Abang, Bapak, Ibuk, Ustad, Ustadzah, Haji, and Hajjah

\begin{tabular}{|c|c|}
\hline Lolo Language & English \\
\hline Nanggut aje akeu ngajui. & $\begin{array}{l}\text { Nanggut please teach me } \\
\text { recitation. }\end{array}$ \\
\hline $\begin{array}{l}\text { Nungguh aje akeu Qal- } \\
\text { qalah }\end{array}$ & $\begin{array}{l}\text { Nungguh please teach me } \\
\text { Qal-qalah. }\end{array}$ \\
\hline $\begin{array}{l}\text { Une lah balik anang } \\
\text { ngajui? }\end{array}$ & $\begin{array}{l}\text { Une are they finish to } \\
\text { recitation? }\end{array}$ \\
\hline $\begin{array}{l}\text { Abang akeu nak balik } \\
\text { ngajui. }\end{array}$ & $\begin{array}{l}\text { Abang I will back to learn } \\
\text { recitation. }\end{array}$ \\
\hline Ibuk nyo ngaheo akeu. & Ibuk she disturb me. \\
\hline Bapak mngui nyo. & Bapak please angry to her. \\
\hline $\begin{array}{l}\text { Ustad apo definisi salah di } \\
\text { dalam islam? }\end{array}$ & $\begin{array}{l}\text { Ustadz what is definition } \\
\text { of wrong in Islam? }\end{array}$ \\
\hline $\begin{array}{l}\text { Ustadzah apa hukuman } \\
\text { bagi orang berbohong? }\end{array}$ & $\begin{array}{l}\text { Ustadzah what is the price } \\
\text { for lier? }\end{array}$ \\
\hline Haji Dahlan lah balik. & Haji Dahlan is back. \\
\hline Hajjah Khadijah lapar. & Hajjah khadijah is hungry. \\
\hline
\end{tabular}

\subsection{The Differences Between Jujun Dialect with Lolo Dialect}

Jujun village and Lolo village is the village who near one each other. Cause of that there are similarities between these of two language. But its also have differences for greeting words. And in this point researcher will show reader many of differences between two dialect of Jujun Village and lolo Village in greeting words.

3.3.1 In General Greeting Words

In Jujun only have one greeting word for uncle (Mamak) and aunt (Itek). In other ways Lolo dialect have tho kind of greeting words of uncle with Mamak and Pak Itek, aunty with Datung and Itek.

In Jujun dialect have one greeting word for grandmother (Nineak) and grandfather (Datuk), but in Lolo dialect have two greeting words of grandmother with Ninek and Nungguh and grandfather with Nakek and Nanggut.

In Jujun dialect have two greeting words of mother with Mak and Induok and father with Abak and Apiak, suddenly in Lolo dialect only have one greeting word, it is Mak and Abak.

In Jujun dialect the sister of mother or father only with Mak Woa is the oldest sister of mother or father and Mak Ngah is the middle sister of mother or father. But in Lolo dialect have many greeting words like Mak Tuo for oldest sister of mother. Mak Ngah is the middle sister of mother. Mak Cik is the youngest sister of mother. Mak Itam is call for middle sister of father. Mak Utih is the middle sister of mother. And Mak $C u$ is the youngest sister of father.

In jujun dialect the brother of mother or father only wth Yah Woa is the oldest brotherof mother or father and Yah Ngah is the middle brother of mother or father. In another ways Lolo dialect have Pak Tuo for oldest brother of mother. Pak Ngah is the middle brother of mother. Pak Cik is the youngest brother of mother. Pak Itam is call for 
middle brother of father. Pak Utih is the middle brther of father and $\mathrm{Pak} C u$ is the youngest brother of father,

In Jujun dialect only have one greeting word to call older brother with Abang and older Sister is Kakak. But in Lolo dialect have two kinds older brother with $U d a$ or Abang and Older Sister with Une or Kakak.

In Jujun dialect have a call for little brother or younger brother with Adiek Jantien or Adik Jantien and Adiek Tinuo or Adik Tinuo for younger sister. But in Lolo dialect have no greeting words for that. To call yunger brother only with you I English with Mpuan for man and Kaau for Woman.

In Jujun dialect there are two kind greeting words of mother of grandfather or grandmother with Nunyang. Its are Nunyang Jantien for man and Nunyang Tinuo for woman. But in Lolo dialect just call with Nunyang all gender.

\section{CONCLUSION}

There are 42 greeting words in Jujun dialect of Kerinci regency who have 32 general greeting words its are Apiak, Abak, Induok, Mak, Mamak, Itek, Datuk, Nineak, Nunyang Jantien, Nunyang Tinuo, Mak Woa, Yah Woa, Mak Ngah, Yah Ngah, Awak, Kayoa, Cik, Abang, Kakak, Adik/Adiek Jantien, Adik/Adiek Tinuo, Apok, Induk, Kulaut, Kanaut, Akau, Ikoa, Kaau, Kamai, Kitoa, Mpaon, and Nyoa, 6 customary greeting words its are Hulubalang, Depati, Ninik Mamak, Pemangku Adat, Pungkoa, and Taganui, 4 religious greeting words its are Buya, Guriu, Haji, and Hajjah. In Lolo dialect have 52 greeting words. 37 general greeting words with Abak, Mak, Datung, Mamak, Itek, Pak Itek, Mak Tuo, Mak Cik, Mak Ngah, Pak tuo, Pak Cik, Pak Ngah, Nakek, Ninek, Nungguh, Nanggut, Uda, Abang, Une, Kakak, Nunyang, Mak Itam, Mak utih, Mak Cu, Pak Itam, Pak Utih, Pak Cu, Akeu, Muan, Kaau, Nyo, Anang, Kamui, Kito, Awak, Kayo, and Iko. Lolo dialect have 5 cistomary greeting words its are Depati, Datuk, Nini Mamak, Sultan, and Puti/Putoi. Lolo dialect also have 10 religious greeting words its are Nanggut, Nangguh, Une, Abang, Ibuk, Bapak, Haji, Hajjah, Ustad, and Ustadzah. If there are many similarities between these two of near village in Kerinci regency, Jambi, Indonesia. But also have many differences and it makes local language or local dialect be unique and be identity of these are villages

\section{ACKNOWLEDGMENT}

The researcher wanna say so thank you so much for all people who contributies in this research. Especially for Mrs. Nurwaida, S.Pdi and Mr Nasri Gusti for informant in Jujun language to collected the data of this research. Also big thank for Mr Andika Saputra, S. Pd and Mrs. Ika Harleni, S.Pd for informants for Lolo language. Thank you so much cause want to help and work together with researcher for entering the data who researcher need.

\section{REFERENCES}

[1] E. Ambarita, "Ancaman Kepunahan BahasaBahasa Daerah Di Era Globalisasi- Sebab-
In Jujun dialect there is a call for lover children with Kulaut and Kanaut but in Lolo dialect nothing.

In Jujun dialect only have Ikoa to say They, but in Lolo dialect have two kinds. Its are Iko and Anang.

3.3.2 In Costumary Greeting Words

In Jujun dialect have 6 greeting words for customary. Its are Hulubalang, Depati, Ninik Mamak, Pemangku Adat, Pungkoa and Taganui. But in Lolo dialect have 5 greeting words with Depati, Ninik Mamak, Datuk, Sultan, and Puti or Putoi.

\subsubsection{In Religious Greeting words}

In Jujun dialect have 4 religious greeting words. Its Buya, Guriu, Haji, and Hajjah. But Lolo dialect have 10 religious greetisng words. Its are Nanggut, Nungguh, Une, Abang, Ibuk, Bapak, Haji, Hajjah, Ustad, and Ustadzah.

W. Wolfram, "The Case of the Ocracoke Brogue," Shima Int. J. Res. into Isl. Cult., vol. 2, no. 1, pp. 1-13, 2008.

[3] H. Skirgård, S. G. Roberts, and L. Yencken, Why are some languages confused for others? Investigating data from the great language game, vol. 12 , no. 4. 2017.

[4] E. A. McCullough, C. G. Clopper, and L. Wagner, "Regional dialect perception across the lifespan: Identification and discrimination," Lang. Speech, vol. 62, no. 1, pp. 115-136, 2019, doi: $10.1177 / 0023830917743277$

[5] A. Al-thubaity, Q. Alqahtani, and A. Aljandal, "ScienceDirect ScienceDirect ScienceDirect Sentiment lexicon for sentiment analysis of Saudi dialect tweets Sentiment lexicon for sentiment analysis of Saudi dialect tweets," Procedia Comput. Sci., vol. 142, pp. 301-307, 2018, doi: 10.1016/j.procs.2018.10.494.

[6] Misnawati, "Kata sapaan bahasa minangkabau: penggunaan dan kategorisasi," J. Elektron. WACANA Etn., vol. 8, no. 1, pp. 13-20, 2017.

[7] C. E. Potter and J. R. Saffran, "Exposure to multiple accents supports infants' understanding of novel accents," Cognition, vol. 166, pp. 67-72, 2017, doi: 10.1016/j.cognition.2017.05.031.

[8] M. R. Myers-burg, "The Role of Dialect Words in Children' s Social Decisions," University of Arkansas, 2018.

[9] L. Wagner, C. G. Clopper, and J. K. Pate, "Children's perception of dialect variation," $J$. Child Lang., vol. 41, no. 5, pp. 1062-1084, 2014, doi: 10.1017/S0305000913000330.

[10] I. Setiawan, "Social Dialect Variations in Sasak Monolingual Society: A Lingual Critical Study," Int. J. Linguist. Lit. Cult., vol. 1, no. 1, pp. 1-8, 2015, doi: 10.21744/ijllc.v1i1.101.

[11] M. Shariati and S. M. Tayebi, "A Comparative Study of Proverbs' Characteristics of Mesopotamian Language, and a Local Dialect of 
Persian," Int. J. English Linguist., vol. 2, no. 2, 2012, doi: 10.5539/ijel.v2n2p141.

[12] H. Karacan, "Kurmanji and Zazaki Dialects: Comparative Study on their Phonetics," Int. J. Kurd. Stud., no. January, pp. 35-51, 2019, doi: 10.21600/ijoks.653812.

[13] S. Barbu, N. Martin, J. Chevrot, R. Dodsworth, and N. Carolina, "The maintenance of regional dialects : a matter of gender? Boys, but not girls, use local varieties in relation to their friends nativeness and local identity," vol. 5, no. October, pp. 1-11, 2014, doi: 10.3389/fpsyg.2014.01251.

[14] M. Paquette-smith, H. Buckler, K. S. White, and E. K. Johnson, "The Effect of Accent Exposure on Children 's Sociolinguistic Evaluation of Peers," vol. 55, no. 4, pp. 809-822, 2019, doi: http://dx.doi.org/10.1037/dev0000659.

[15] I. A. U. Al-Qaderi, "Conversational Implicature in Arabic: A Pragmatic Analysis of Applying Flouting the Maxims to the Yemeni Dialect," Int. J. Linguist., vol. 7, no. 6, p. 53, 2015, doi: 10.5296/ijl.v7i6.8745.

[16] Y. Gong, I. H. siu Chow, and D. Ahlstrom, "Cultural diversity in China: Dialect, job embeddedness, and turnover," Asia Pacific J. Manag., vol. 28, no. 2, pp. 221-238, 2011, doi: $10.1007 / \mathrm{s} 10490-010-9232-6$.

[17] R. Indrawaswari, "Kata Sapaan dalam Dialek Jawa Banten: (Studi Kasus Dialek Jawa Banten Dalam Ranah Keluarga Dan Ketetanggaan Pada
Perkampungan Margagiri Kelurahan Margatani),” Universitas Diponegoro, 2013.

[18] R. Setyarini, “Analisis Pengunaan Kata sapaan Pada Judul Berita Tabloid Soccer," Universitas Muhammadiyah Surakarta, 2014.

[19] A. A. Perwira, "Variasi Bahasa Sapaan jual Beli Pedagang Pasar Klitikan di Semanggi Surakarta pada Bulan desember 2012," Universitas muhammadiyah Surakarta, 2012.

[20] W. Rusbiyantoro, "Penggunaan Kata Sapaan Dalam Bahasa Melayu Kutai," Parol. J. Linguist. Educ., vol. 2, no. 1 April, pp. 59-76, 2011, doi: 10.14710/parole.v2i1 April.1575.

[21] V. Y. Aditama, "Pengunaan sapaan bahasa kerinci dialek jujun,” BASINDO J. Kaji. Bahasa, sastra Indones. dan Pembelajarannya, vol. 4, pp. 135143, 2020, [Online]. Available: http://creativecommons.org/licenses/BY/4.0/.

[22] Iskandar, Metodologi PenelitianPendidikan dan Sosial (Kuantitatif dan Kualitatif). Jakarta, Indonesia: Gp Press, 2008.

[23] Sugiyono, "Metode Penelitian Pendidikan Pendekatan Kuantitatif, Kualitatif, dan R\&D." Alfabeta, Bandung, Indonesia, 2014.

[24] Mahsun, "Metode Penelitian Bahasa: Tahap, Strategi dan Tekniknya." Raha Grafindo Persada, Jakarta, Indonesia, 2007. 